\title{
SCIDiC
}

International Journal of Dentistry and Oral Science (IJDOS)

ISSN: 2377-8075

\section{Prevalence Of Gingivitis In Patients Undergoing Orthodontic Treatment Of Ages 18-25 Years- A Retrospective Study}

Research Article

Kirtana Gopalasamy ${ }^{1}$, Jaiganesh Ramamurthy ${ }^{2 *}$, Pradeep D

${ }^{1}$ Saveetha Dental College and Hospitals, Saveetha Institute of Medical and Technical Sciences, Saveetha University, Chennai, India.

${ }^{2}$ Professor and Head, Department of Periodontics, Saveetha Dental College and Hospitals, Saveetha Institute of Medical and Technical Sciences, Saveetha University, Chennai, 600077, India.

${ }^{3}$ Associate Professor, Department of Oral and Maxillofacial Surgery, Saveetha Dental College and Hospitals, Saveetha Institute of Medical and Technical Sciences, Saveetha University, Chennai, 600077, India.

\section{Abstract}

The use of fixed Orthodontics made of wire and brackets is a common treatment that can affect the gingival health. The constant irritation and poor maintenance in patients may lead to gingival inflammation if not maintained properly .Improper oral hygiene during the course of orthodontic treatment is the leading reason for the cause of gingivitis . 18- 25 years is the most common age where majority of the current population undergo orthodontic treatment for aesthetic look, this makes it an appropriate age of study to see the improper oral hygiene leading to be the cause of gingivitis in many. The purpose of this study was to evaluate the association of orthodontic treatment and gingival health in those patients .Evaluation of 225 patients of age group 18-25 years undergoing Orthodontic treatment in Saveetha Dental College between June 2019 to March 2020 was done and they were also evaluated for the presence of gingivitis . Excel tabulation was done and data was imported to SPSS to generate results From the study we were able to evaluate and see that gingivitis was most often present in patients undergoing orthodontic treatment .Gingival Heath is very important and in patients undergoing orthodontic treatment, due to poor maintenance, presence of plaque increases hence leading to gingivitis.

Keywords: Biofilm; Dental Plaque; Gingiva; Gingivitis; Oral Hygiene; Orthodontic Treatment.

\section{Introduction}

Periodontics and Orthodontic treatment interrelationship has been a subject to a lot of theories and investigation over the last decade until today, and still remains debatable. Dental and skeletal malocclusion has over the years shown to affect the gingival and periodontal health directly and indirectly [1-5]. The main aim of orthodontic treatment is at the betterment of occlusion inorder to improve dental health and prolong the health and life of dentition [6-11]. Orthodontic treatment aims at the betterment of dental hygiene and this is mainly done by correcting the dental malocclusion and this helps in reducing the occlusal trauma. Occlusal trauma when reduced helps in reducing the trauma to the gingiva and periodontitis and helps in preventing the inflammation. As the malocclusion is corrected the reduction in crowding or cross bite or other malocclusion features helps in reducing the trauma with the patients able to maintain their teeth better and hence improving dental health [12].

There needs to be maintained a proper balance between health and disease in the periodontium. This depends on the absence or presence of supra and sub gingival plaque accumulation. Accumulation of supra gingival plaque leads to gingivitis [13]. In some studies, poor oral hygiene increased the occurrence of gingival enlargement $[14,15]$. Other clinical studies concluded that overall gingival changes during orthodontic treatment are transient with no permanent damage to the periodontal supporting tissues [1621]. The presence of orthodontic brackets and wires directly or indirectly led to development of gingivitis and periodontitis. It takes skill and effort to maintain oral hygiene during orthodontic treatment especially in the interproximal surfaces. Previously done microbiological studies show that when fixed orthodontic

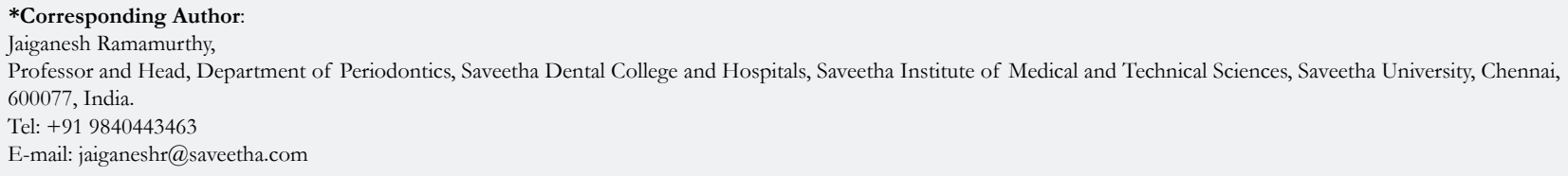

Citation: Kirtana Gopalasamy, Jaiganesh Ramamurthy, Pradeep D. Prevalence Of Gingivitis In Patients Undergoing Orthodontic Treatment Of Ages 18 -25 Years- A Retrospective Study. Int J Dentistry Oral Sci. 2020;7(12):1231-1235. doi: http://dx.doi.org/10.19070/2377-8075-20000243

Copyright: Jaiganesh Ramamurthy ${ }^{\circ}$ 2020. This is an open-access article distributed under the terms of the Creative Commons Attribution License, which permits unrestricted use, distribution and reproduction in any medium, provided the original author and source are credited. 
appliances are placed, the potential for quantitative [22, 23] and qualitative $[24,25]$ changes in the microbial composition of these areas increases. Therefore, periodontal inflammation might be elicited by a change in the microbiological environment.

Plaque composition is greatly dependent on the host and response. Initial plaque formation is mainly due to the pioneer species which adhere to the salivary proteins and to the glycoproteins. The pioneer species include Neisseria, Streptococci predominantly S.sanguis, Soralis and S.mitis. These initial pioneer species grow and multiply leading to the secondary colonisation by Gram positive and negative species creating a biofilm [26].

The role of bacteria in dental caries was proven through experimentation by match, leading to the formation of white spot lesions. In a study conducted by [27] he suggested that up to $50 \%$ of the patients who underwent orthodontic treatment developed white spot lesions during the treatment. In the previous years as seen in the literature, epidemiological and experimental studies have shown a strong association between the presence of dental plaque in the oral cavity leading to the development of gingival and periodontal diseases [28]. There are mainly two types of periodontal disease of which, gingivitis is associated with reversible destruction of the periodontal tissues and periodontitis which is associated with irreversible pattern of destruction in the form of periodontal attachment loss [29]. The hypothesis mainly shows us that the inflammation leads to increased flow of gingival crevicular fluid which leads to an increase in $\mathrm{pH}$ and temperature which helps in the growth of proteolytic obligate anaerobic species associated with periodontal diseases [26].

Orthodontic appliances, as well as procedures involving correction of tooth are Prone to local soft tissue responses in the gingiva. The close proximity of orthodontic appliances to gingival sulcus increases the plaque accumulation on improper maintenance leading to plaque formation $[30,31]$. Following the insertion of orthodontic appliances in the oral cavity it can contribute to chronic infection, inflammatory hyperplasia, loss of attachment, gingival recession. Many investigations have shown that gingival recession to be associated with labial movement of mandibular incisors and have been associated with risk factors for gingival recession $[32,33]$.

The age range of the following study is very important as 1825 years is one of the most important phases where a patient can either choose to maintain their oral health properly or not. The strong inclination of plaque accumulation in 18-25 years and towards gingivitis and eventually periodontitis in the later adult years If not treated properly and looked after now is one of the important factors in this study.

Gingival overgrowth is a very common condition in the orthodontic population that is characterised by gingival enlargement possibly resulting in pseudo-pocketing with or without attachment loss. When involving the anterior region, it may have an impact on oral health-related quality of life [34]. The presence of gingival enlargement in the interdental papillae can be due to the application of continuous compressive or retraction forces to correct crowding and spacing. Orthodontic space closure of extraction sites may result in gingival invagination or growth of gingival tissue $[35,36]$.
Mucogingival surgery during orthodontic treatment corrects soft tissue characteristics in order to create more favourable conditions for the mechanical stress resistance. Even though improved gingival characteristics may not guarantee the absence of gingival recession after orthodontic therapy especially when significant dental arch expansion or labial proclination is performed and a second surgery may be needed after the end of orthodontics. Mechanical forces applied during the course of orthodontic treatment results in bone changes such as resorption, and changes in the periodontal ligament and osseous structure. Mild orthodontic forces along with proper strict oral hygiene may control the bone changes.

The aim of this study was to evaluate the relationship between orthodontic treatment and gingivitis in the age group of 18-25 years.

\section{Materials and Methods}

\section{Study Setting}

The study was conducted with the approval of the Institutional Ethics Committee [SDC/SIHEC/2020/DIASDATA/0619-0320]. The study consisted of one reviewer, one assessor and one guide.

\section{Study Design}

The study was designed to include all dental patients of the ages 18-25 years undergoing orthodontic treatment. The patients who did not fall into this inclusion criteria were excluded.

\section{Sampling Technique}

The study was based on a non probability consecutive sampling method. To minimise sampling bias, all case sheets of patients who underwent Orthodontic treatment were reviewed and included.

\section{Data Collection and Tabulation}

Data Collection was done using the patient database with the timeframe work 01 June 2019 and 31 march 2020. About 225 case sheets were reviewed and those fitting under the inclusion criteria were included. Cross verification was done with the help of Photographs and radiographic evidence. To minimise sampling bias all data were included. The exclusion criteria was patients with systemic illness. Data was downloaded from DIAS and imported to Excel, Tabulation was done. The values were tabulated and analysed.

\section{Statistical Analysis}

Descriptive statistics were performed using SPSS by IBM on the tabulated values. Chi-Square test was performed and the $\mathrm{p}$ value was determined to evaluate the significance of the variables it was used to evaluate the association between the age and gender with the prevalence of gingivitis in patients undergoing orthodontic treatment. The results were obtained in the form of graphs and tables. 


\section{Results and Discussion}

It was seen that out 225 patient that were undergoing orthodontic treatment, $76 \%$ of the patients, had generalised chronic gingivitis, $15 \%$ of them had clinically healthy gingiva, $7 \%$ of them had localised chronic periodontitis and $2 \%$ of them presented with generalised chronic periodontitis.

The research also helps us see that on the basis of age, generalised chronic gingivitis was the most common gingival condition seen in both the age groups. While localised chronic periodontitis was high in the age group 22-25 years and generalised chronic periodontitis was also seen only in the $22-25$ years age group.

Based on gender wise distribution of gingivitis among patients undergoing orthodontic treatment, gingivitis was present at a higher number in males. While in females generalised chronic periodontitis was seen to be higher in females while localised chronic periodontitis was seen to be higher in males.

The main reason why orthodontic treatment is done is to improve facial aesthetics and dental health and function in a review conducted by Bollen et al., [12], it was seen that there was a correlation between the presence of a malocclusion and periodontal disease. Subjects with greater malocclusion have more severe periodontal disease. The patient's inability to clean his or her teeth adequately around fixed orthodontic devices promotes plaque accumulation that can then lead to gingival inflammation. An overall increase in salivary bacterial counts, especially Lactobacillus, has been shown after orthodontic appliance [37] placement. Similarly, one study showed an early increase in anaerobes and Prevotellaintermedia, and a decrease in facultative anaerobes [38].

From the study we were also able to see that the lower anterior region was the area most susceptible for gingival inflammation and also localised chronic periodontitis in severe cases. They were statistically significant in patients undergoing orthodontic treatment . According to a study done by Zachrisson et al ,1972 [39, 40] it was seen that even after maintaining excellent oral hygiene, patients usually experience Mild to moderate gingivitis within 1-2 months on placing the orthodontic appliance.

Based on another study conflicted by Liu et al, 2011 [41] he suggested that in patients undergoing orthodontic treatment there resulted in dental plaque and calculus deposition eventually leading to gingival inflammation leading to gingivitis and eventually periodontitis. There being a sufficient increase in the plaque index and gingival index. Based on another study reported by Davies et al, 1991 [42] showed the difference in the gingival health in patients undergoing orthodontic treatment when compared to those not undergoing orthodontic treatment, and regular visits to the dentist showed improvement in dental health.

When a comparative evaluation was done orthodontic tooth movement and gingival recession has been mentioned in both orthodontic and periodontal literature, with some reports arguing on behalf of a causal connection and others arguing against it [43-45]. The age limit in our study was kept at 18 years at the baseline of orthodontic treatment. In a study conducted by Vassali et al. [46]. He reported that treatment duration, treatment type, the skeletal or dental relationship did not affect the development of recessions during treatment. Presence of gingival inflammation

Table 1. Describes the distribution of study population based on age and gender. It is found that the majority of the participants undergoing orthodontic treatment are of the age group 22-25 years. More males $(19.56 \%)$ were present in the age group of $18-21$ years ,and $22-25$ years $(38.67 \%)$. It can be inferred from this that Males undergoing orthodontic treatment are at greater risk for gingivitis if oral hygiene is compromised during the course of treatment.

\begin{tabular}{|c|c|c|c|}
\hline Age & Females & Males & Total \\
\hline $18-21$ & $42(18.67 \%)$ & $44(19.56 \%)$ & 86 \\
\hline $22-25$ & $52(23.11 \%)$ & $87(38.67 \%)$ & 139 \\
\hline Total & $94(41.78 \%)$ & $131(58.23 \%)$ & $225(100 \%)$ \\
\hline
\end{tabular}

Table 2. Describes the age wise distribution of gingivitis among patients undergoing orthodontic treatment.

\begin{tabular}{|c|c|c|c|}
\hline & Value & df & Asymptotic Significance(2-sided) \\
\hline Pearson Chi-Square & $6.874^{\mathrm{a}}$ & 3 & 0.076 \\
\hline Likelihood ratio & 8.104 & 3 & 0.044 \\
\hline N.of valid cases & 225 & & \\
\hline
\end{tabular}

Figure 1. The graph represents the distribution of Gingival health among patients undergoing orthodontic treatment . $\mathrm{X}$ axis - Gingival health ; $\mathrm{Y}$ axis - Number of patients undergoing orthodontic treatment. It was observed from this graph that $76 \%$ of patients undergoing orthodontic treatment had Generalised chronic gingivitis implying that Generalised chronic gingivitis was the most commonly present gingival disease among patients undergoing orthodontic treatment.

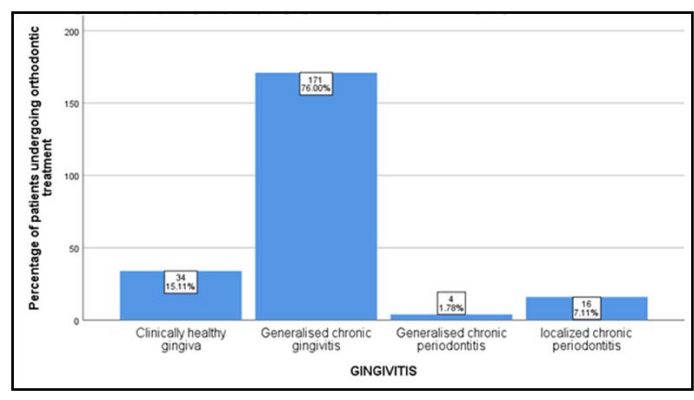


Figure 2. The graph represents the association between the age and the treatment undergone by the patient. $\mathrm{X}$ axis represents the age distribution . Y axis represents the total number of patients. There was a higher predilection of generalised chronic gingivitis in the age group $22-25$ years. However there was no significant association between age and gingivitis in the orthodontic treatment . Pearson Chi Square value $-6.874 a, p$ value- 0.076 , $p$ value $>0.05$ statistically not significant.

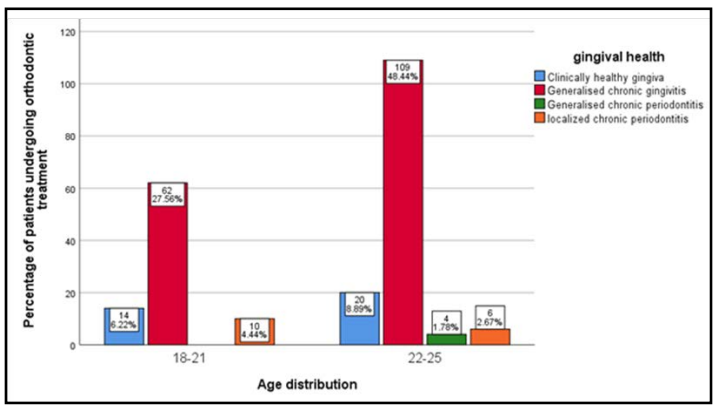

Figure 3. The graph represents the association between the gender and the treatment undergone by the patient. $\mathrm{X}$ axis represents the gender distribution. Y axis represents the total number of patients.There was a higher predilection of generalised chronic gingivitis in males . However there was no significant association between age and gingivitis in the orthodontic treatment. Pearson Chi Square value- $2.778 \mathrm{a}, \mathrm{p}$ value- 0.427 , $\mathrm{p}$ value $>0.05$ statistically not significant.

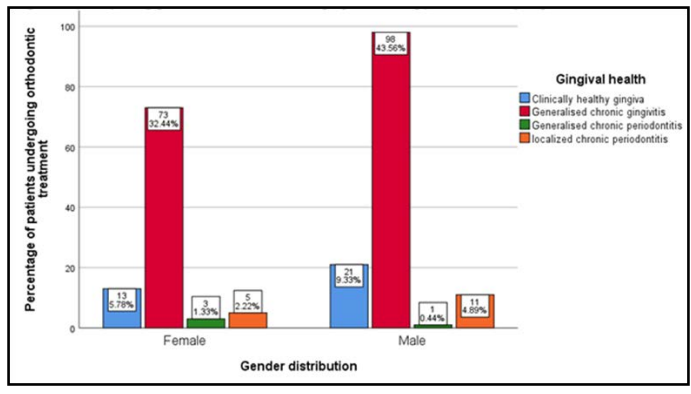

and baseline recession narrow keratinized gingiva [33].

Based on a few studies conducted to evaluate the relationship between gingival recession and orthodontic treatment, it showed that gingival recession there was an increase in their prevalence in older adolescents and adults undergoing orthodontic treatment. But there was a more favourable outcome in the older age group. According to a study conducted by Dorfman et al [32]. It was seen that proclination of the lower incisors during the orthodontic treatment had a detrimental effect on the periodontal health, where studies showed that proclined teeth had higher probability to show gingival inflammation then the untreated teeth.

Oral hygiene instruction and demonstrations must effectively take place during orthodontic treatment. Certain patients need to be reminded to concentrate on cleaning the cervical area of their teeth below the brackets. A continuous increase in oral hygiene awareness not only will reduce the prevalence and severity of iatrogenic tissue damage but also will extend the long-term benefits of orthodontic therapy. From a study conducted by Rajan K et al [47]. He reported that about $68 \%$ of the patients that he assessed did not visit a dental hygienist during their orthodontic treatment. Hence this leading to the increase in gingivitis among patients undergoing orthodontic treatment is negligence to their oral health. Orthodontic patients, in particular, must be trained in proper oral hygiene maintenance and their brushing procedures must be checked regularly.

In a study conducted by Sallum et al. [48], have reported a significant reduction in plaque index, bleeding on probing, and probing depth, the three most important parameters indicating clinical gingival health, once orthodontic appliances are removed. From our study we were able to see that orthodontic treatment played an impact in gingival health and plaque accumulation over the orthodontic appliance is responsible for causing gingival inflammation. The presence of gingivitis was very common in young adolescents and adults and the age group 18-25 years. Hence orthodontic patients should be reinforced to follow strict oral hygiene protocol to maintain optimal gingival health.

\section{Conclusion}

Within the limits of the present study, it can be concluded that there was a high prevalence of gingivitis in patients undergoing orthodontic treatment. We were able to see that gingivitis was very common in patients undergoing Orthodontic treatment specifically in the age group of $22-25$ years. Considering the relationship between orthodontic treatment and gingival health, patients and orthodontists must cooperate and consult with periodontists during the treatment for a favourable outcome.

\section{Acknowledgement}

I would like to thank Saveetha Dental College for the constant encouragement with my work during all stages.

\section{References}

[1]. Thamaraiselvan M, Elavarasu S, Thangakumaran S, Gadagi JS, Arthie T. Comparative clinical evaluation of coronally advanced flap with or without platelet rich fibrin membrane in the treatment of isolated gingival recession. J Indian SocPeriodontol. 2015 Jan-Feb;19(1):66-71. PubmedPMID: 25810596.

[2]. Ramesh A, Varghese SS, Doraiswamy JN, Malaiappan S. Herbs as an antioxidant arsenal for periodontal diseases. J IntercultEthnopharmacol. 2016 Jan 27;5(1):92-6. PubmedPMID: 27069730.

[3]. Varghese SS, Thomas H, Jayakumar ND, Sankari M, Lakshmanan R. Estimation of salivary tumor necrosis factor-alpha in chronic and aggressive periodontitis patients. ContempClin Dent. 2015 Sep;6(Suppl 1):S152-6. PubmedPMID: 26604566. 
[4]. Shivakumar K, Chandu G, Shafiulla M. Severity of Malocclusion and Orthodontic Treatment Needs among 12- to 15-Year-Old School Children of Davangere District, Karnataka, India. Eur J Dent. 2010 Jul;4(3):298-307. Pubmed PMID: 20613919.

[5]. Avinash K, Malaippan S, Dooraiswamy JN. Methods of Isolation and Characterization of Stem Cells from Different Regions of Oral Cavity Using Markers: A Systematic Review. Int J Stem Cells. 2017 May 30;10(1):12-20. PubmedPMID: 28531913.

[6]. Panda S, Jayakumar ND, Sankari M, Varghese SS, Kumar DS. Platelet rich fibrin and xenograft in treatment of intrabony defect. ContempClin Dent. 2014 Oct;5(4):550-4. PubmedPMID: 25395778.

[7]. Mootha A, Malaiappan S, Jayakumar ND, Varghese SS, Toby Thomas J. The Effect of Periodontitis on Expression of Interleukin-21: A Systematic Review. Int J Inflam. 2016;2016:3507503. PubmedPMID: 26998377.

[8]. Ravi S, Malaiappan S, Varghese S, Jayakumar ND, Prakasam G. Additive Effect of Plasma Rich in Growth Factors With Guided Tissue Regeneration in Treatment of Intrabony Defects in Patients With Chronic Periodontitis: A Split-Mouth Randomized Controlled Clinical Trial. J Periodontol. 2017 Sep;88(9):839-845. PubmedPMID: 28474968.

[9]. Khalid W, Varghese SS, Sankari M, Jayakumar ND. Comparison of serum levels of endothelin-1 in chronic periodontitis patients before and after treatment. Journal of Clinical and Diagnostic Research: Jcdr. 2017 Apr;11(4):ZC78.

[10]. Khalid W, Vargheese SS, Lakshmanan R, Sankari M, Jayakumar ND. Role of endothelin-1 in periodontal diseases: A structured review. Indian J Dent Res. 2016 May-Jun;27(3):323-33. PubmedPMID: 27411664.

[11]. Boke F, Gazioglu C, Akkaya S, Akkaya M. Relationship between orthodontic treatment and gingival health: A retrospective study. Eur J Dent. 2014 Jul;8(3):373-380. doi: 10.4103/1305-7456.137651. PubmedPMID: 25202219.

[12]. Bollen AM, Cunha-Cruz J, Bakko DW, Huang GJ, Hujoel PP. The effects of orthodontic therapy on periodontal health: a systematic review of controlled evidence. The Journal of the American Dental Association. $2008 \mathrm{Apr}$ 1;139(4):413-22

[13]. Antoniazzi RP, Miranda LA, Zanatta FB, Islabão AG, Gustafsson A, Chiapinotto GA, Oppermann RV. Periodontal conditions of individuals with Sjögren's syndrome. J Periodontol. 2009 Mar;80(3):429-35. PubmedPMID: 19254127

[14]. Reali L, Zuliani E, Gabutti L, Schönholzer C, Marone C. Poor oral hygiene enhances gingival overgrowth caused by calcineurin inhibitors. J Clin Pharm Ther. 2009 Jun;34(3):255-60. PubmedPMID: 19646074

[15]. Somacarrera ML, Lucas M, Scully C, Barrios C. Effectiveness of periodontal treatments on cyclosporine-induced gingival overgrowth in transplant patients. Br Dent J. 1997 Aug 9;183(3):89-94. PubmedPMID: 9282449.

[16]. Ramesh A, Varghese SS, Jayakumar ND, Malaiappan S. Chronic obstructive pulmonary disease and periodontitis-unwinding their linking mechanisms. journal of oral biosciences. 2016 Feb 1;58(1):23-6.

[17]. Kavarthapu A, Thamaraiselvan M. Assessing the variation in course and position of inferior alveolar nerve among south Indian population: A cone beam computed tomographic study. Indian Journal of Dental Research. 2018 Jul 1;29(4):405.

[18]. Ramesh A, Ravi S, Kaarthikeyan G. Comprehensive rehabilitation using dental implants in generalized aggressive periodontitis. J Indian SocPeriodontol. 2017 Mar-Apr;21(2):160-163. PubmedPMID: 29398863.

[19]. Ramesh A, Vellayappan R, Ravi S, Gurumoorthy K. Esthetic lip repositioning: A cosmetic approach for correction of gummy smile - A case series. J Indian SocPeriodontol. 2019 May-Jun;23(3):290g-294. PubmedPMID: 31143013.

[20]. Gomes SC, Varela CC, da Veiga SL, Rösing CK, Oppermann RV. Periodontal conditions in subjects following orthodontic therapy. A preliminary study. Eur J Orthod. 2007 Oct;29(5):477-81. PubmedPMID: 17693428.

[21]. Sadowsky C, BeGole EA. Long-term effects of orthodontic treatment on periodontal health. Am J Orthod. 1981 Aug;80(2):156-72. PubmedPMID: 6943936.

[22]. Diamanti-Kipioti A, Gusberti FA, Lang NP. Clinical and microbiological effects of fixed orthodontic appliances. J ClinPeriodontol. 1987 Jul;14(6):32633. J ClinPeriodontol. 1990 Jan;17(1):66.Pubmed PMID: 3509967.

[23]. Paolantonio M, Festa F, di Placido G, D'Attilio M, Catamo G, Piccolomini R. Site-specific subgingival colonization by Actinobacillusactinomycetemcomitans in orthodontic patients. Am J OrthodDentofacialOrthop. 1999 Apr;115(4):423-8. PubmedPMID: 10194288.

[24]. Ristic M, VlahovicSvabic M, Sasic M, Zelic O. Clinical and microbiological effects of fixed orthodontic appliances on periodontal tissues in adolescents. OrthodCraniofac Res. 2007 Nov;10(4):187-95. PubmedPMID: 17973685.

[25]. Yoo SY, Kim M, Kim S, Kim SH, Ko SJ, Beom JW, et al. Relationship between obesity indices and cardiovascular risk score in Korean type 2 diabetes patients. The Korean Journal of Obesity. 2013 Sep 30;22(3):148-54.
[26]. Marsh P, Martin M. Oral microbiology. Background and introduction. Oral Microbiology 1992; 1-5.

[27]. Gorelick L, Geiger AM, Gwinnett AJ. Incidence of white spot formation after bonding and banding. American journal of orthodontics. 1982 Feb 1;81(2):93-8.

[28]. Löe H, Theilade E, Börglum Jensen S. Experimental Gingivitis in Man Journal of Periodontology 1965; 36: 177-187.PubmedPMID: 14296927.

[29]. Armitage GC. Development of a classification system for periodontal diseases and conditions. Ann Periodontol. 1999 Dec;4(1):1-6. PubmedPMID: 10863370.

[30]. Boyd RL. Longitudinal evaluation of a system for self-monitoring plaque control effectiveness in orthodontic patients. J ClinPeriodontol. 1983 Jul;10(4):380-8. PubmedPMID: 6577031.

[31]. Willmot D. Orthodontic treatment and the compromised periodontal patient. Eur J Dent. 2008 Jan;2(1):1-2. PubmedPMID: 19212501.

[32]. Dorfman HS. Mucogingival changes resulting from mandibular incisor tooth movement. Am J Orthod. 1978 Sep;74(3):286-97. PubmedPMID: 281132 .

[33]. Hollender L, Rönnerman A, Thilander B. Root resorption, marginal bone support and clinical crown length in orthodontically treated patients. Eur J Orthod. 1980;2(4):197-205. PubmedPMID: 6961039.

[34]. Zanatta FB, Ardenghi TM, Antoniazzi RP, Pinto TM, Rösing CK. Association between gingival bleeding and gingival enlargement and oral healthrelated quality of life (OHRQoL) of subjects under fixed orthodontic treatment: a cross-sectional study. BMC Oral Health. 2012 Nov 27;12:53. PubmedPMID: 23186371.

[35]. Kurol J, Rönnerman A, Heyden G. Long-term gingival conditions after orthodontic closure of extraction sites. Histological and histochemical studies. Eur J Orthod. 1982 May;4(2):87-92. PubmedPMID: 6955180.

[36]. Ramamurthy J. COMPARISON OF EFFECT OF HIORA MOUTHWASH VERSUS CHLORHEXIDINE MOUTHWASH IN GINGIVITIS PATIENTS: A CLINICAL TRIAL. Asian J Pharm Clin Res 2018; 11: 84-88.

[37]. Guilford HJ, Grubb TA, Pence DL. Vertical extrusion: a standardized technique. CompendContinEduc Dent. 1984 Jul-Aug;5(7):562-7.Pubmed PMID: 6590201.

[38]. Melsen B. Tissue reaction following application of extrusive and intrusive forces to teeth in adult monkeys. Am J Orthod. 1986 Jun;89(6):469-75. PubmedPMID: 3459360.

[39]. Zachrisson BU, Zachrisson S. Gingival condition associated with partial orthodontic treatment. ActaOdontol Scand. 1972 Mar;30(1):127-36. PubmedPMID: 4504433.

[40]. Priyanka S, Kaarthikeyan G, Nadathur JD, Mohanraj A, Kavarthapu A Detection of cytomegalovirus, Epstein-Barr virus, and Torque Teno virus in subgingival and atheromatous plaques of cardiac patients with chronic periodontitis. J Indian SocPeriodontol. 2017 Nov-Dec;21(6):456-460. PubmedPMID: 29551863.

[41]. Liu H, Sun J, Dong Y, Lu H, Zhou H, Hansen BF, et al. Periodontal health and relative quantity of subgingivalPorphyromonasgingivalis during orthodontic treatment. Angle Orthod. 2011 Jul;81(4):609-15. PubmedPMID: 21306224.

[42]. Davies TM, Shaw WC, Worthington HV, Addy M, Dummer P, Kingdon A. The effect of orthodontic treatment on plaque and gingivitis. Am J OrthodDentofacialOrthop. 1991 Feb;99(2):155-61. Pubmed PMID: 1990825.

[43]. Wennström JL, Lindhe J, Sinclair F, Thilander B. Some periodontal tissue reactions to orthodontic tooth movement in monkeys. J ClinPeriodontol. 1987 Mar; 14(3):121-9. PubmedPMID: 3470318.

[44]. Melsen B, Allais D. Factors of importance for the development of dehiscences during labial movement of mandibular incisors: a retrospective study of adult orthodontic patients. Am J OrthodDentofacialOrthop. 2005 May;127(5):552-61. PubmedPMID: 15877035.

[45]. Yared KF, Zenobio EG, Pacheco W. Periodontal status of mandibular central incisors after orthodontic proclination in adults. Am J OrthodDentofacialOrthop. 2006 Jul;130(1):6.e1-8. PubmedPMID: 16849063.

[46]. Joss-Vassalli I, Grebenstein C, Topouzelis N, Sculean A, Katsaros C. Orthodontic therapy and gingival recession: a systematic review. OrthodCraniofac Res. 2010 Aug;13(3):127-41.Pubmed PMID: 20618715.

[47]. Mahindra RK, Suryawanshi GR, Doshi UH. Effects of fixed orthodontic treatment on gingival health: An observational study.

[48]. Sallum EJ, Nouer DF, Klein MI, Gonçalves RB, Machion L, Wilson Sallum A, et al. Clinical and microbiologic changes after removal of orthodontic appliances. Am J OrthodDentofacialOrthop. 2004 Sep;126(3):363-6. PubmedPMID: 15356501 